\title{
Cell internalization of 7-kearch Paper Cell internalization of 7-ketocholesterol-containing nanoemulsion through LDL receptor reduces melanoma growth in vitro and in vivo: a preliminary report
}

Giovani M. Favero ${ }^{1,2}$, Jessica L. Paz ${ }^{1}$, Andréia H. Otake ${ }^{3,4}$, Durvanei A. Maria ${ }^{5}$, Elia G. Caldini', Raphael S.S. de Medeiros ${ }^{3,4}$, Debora F. Deus 7 , Roger Chammas ${ }^{3,4}$, Raul C. Maranhão ${ }^{7,8}$ and Sergio P. Bydlowski ${ }^{1}$

${ }^{1}$ Laboratory of Genetics and Molecular Hematology (LIM31), Department of Hematology, Hospital das Clinicas HCFMUSP, Faculdade de Medicina, Universidade de Sao Paulo, Sao Paulo, SP, Brazil

${ }^{2}$ Department of General Biology, Universidade Estadual de Ponta Grossa, Ponta Grossa, PR, Brazil

${ }^{3}$ Centro de Investigação Translacional em Oncologia (LIM24), Departamento de Radiologia e Oncologia, Hospital das Clinicas HCFMUSP, Faculdade de Medicina, Universidade de Sao Paulo, Sao Paulo, SP, Brazil

${ }^{4}$ Instituto do Cancer do Estado de Sao Paulo (ICESP), SP, Brazil

${ }^{5}$ Biochemistry and Biophysics Laboratories, Instituto Butantan, Sao Paulo, SP, Brazil

${ }^{6}$ Laboratory for Cell Biology, Department of Pathology, Faculdade de Medicina FMUSP, Universidade de Sao Paulo, Sao Paulo, SP, Brazil

${ }^{7}$ Laboratory of Metabolism and Lipids, Heart Institute (InCor), Hospital das Clinicas HCFMUSP, Faculdade de Medicina, Universidade de Sao Paulo, Sao Paulo, SP, Brazil

${ }^{8}$ Faculdade de Ciencias Farmaceuticas, Universidade de Sao Paulo, Sao Paulo, SP, Brazil

Correspondence to: Sergio P. Bydlowski, email: spbydlow@usp.br

Keywords: 7-ketocholesterol; nanoemulsion; melanoma; cell death; LDL receptor

Received: October 29, 2017 Accepted: January 25, 2018 Epub: February 04, 2018 Published: March 06, 2018

Copyright: Favero et al. This is an open-access article distributed under the terms of the Creative Commons Attribution License 3.0 (CC BY 3.0), which permits unrestricted use, distribution, and reproduction in any medium, provided the original author and source are credited.

\section{ABSTRACT}

Oxysterols are cholesterol oxygenated derivatives which possess several biological actions. Among oxysterols, 7-ketocholesterol (7KC) is known to induce cell death. Here, we hypothesized that $7 \mathrm{KC}$ cytotoxicity could be applied in cancer therapeutics. 7KC was incorporated into a lipid core nanoemulsion. As a cellular model the murine melanoma cell line B16F10 was used. The nanoparticle (7KCLDE) uptake into tumor cells was displaced by increasing amounts of low-density-lipoproteins (LDL) suggesting a LDL-receptor-mediated cell internalization. 7KCLDE was mainly cytostatic, which led to an accumulation of polyploid cells. Nevertheless, a single dose of 7KCLDE killed roughly $10 \%$ of melanoma cells. In addition, it was observed dissipation of the transmembrane potential, evidenced with flow cytometry; presence of autophagic vacuoles, visualized and quantified with flow cytometry and acridine orange; and presence of myelin figures, observed with ultrastructural microscopy. 7KCLDE impaired cytokenesis was accompanied by changes in cellular morphology into a fibroblastoid shape which is supported by cytoskeletal rearrangements, as shown by the increased actin polymerization. 7KCLDE was injected into B16 melanoma tumor-bearing mice. 7 KCLDE accumulated in the liver and tumor. In melanoma tumor 7 KCLDE promoted a $>50 \%$ size reduction, enlarged the necrotic area, and reduced intratumoral vasculature. 7KCLDE increased the survival rates of animals, without hematologic or liver toxicity. Although more pre-clinical studies should be performed, our preliminary results suggested that 7 KCLDE is a promising novel preparation for cancer chemotherapy. 


\section{INTRODUCTION}

Oxysterols are 27-carbon products of cholesterol oxidation that can be formed either by auto-oxidation or by specific enzymatic action $[1,2]$. They represent a large class of biologically important regulatory molecules involved in sterol and lipid metabolism, cell proliferation, and cell differentiation, as well as in pathophysiological processes, such as atherosclerosis, mutagenesis, and carcinogenesis [3-6].

Oxysterols have potent effects on cell death processes in a number of cell lines $[5,7,8]$. The cytotoxicity attributed to most oxysterols is related to their ability to induce apoptosis, through both the extrinsic and intrinsic pathways, and autophagy.

One oxysterol, 7-ketocholesterol (7KC), differs from free cholesterol by the addition of a functional ketone group at $\mathrm{C} 7.7 \mathrm{KC}$ has been extensively studied in different cellular models, where it has been reported to cause death through several mechanisms [9-12]. 7KC was shown to increase membrane permeability and reactive oxygen species (ROS) production, reduce the mitochondrial membrane potential, release cytochrome $\mathrm{C}$, cause nuclear condensation and oxidative damage to DNA, and reduce nitric oxide production and cell proliferation [5, 8, 10-12].

Cell death promoted by oxysterols has been also observed in cancer cell models [13-15]. In view of the ability of $7 \mathrm{KC}$ to induce cell death, its pharmacological use in cancer therapy deserves to be addressed. Moreover, to avoid undesirable actions on normal cells, $7 \mathrm{KC}$ should rather be targeted to tumor cells. In fact, reducing the toxicity of different anti-cancer drugs is a major concern in cancer chemotherapy.

Cholesterol is an essential component for the stability and function of animal cell membranes [16]. Among the lipid molecules that form the membrane structure, roughly half are cholesterol. Malignant neoplastic cells require high levels of cholesterol for membrane synthesis, due to accelerated mitosis; thus, these cells upregulate their production of low density lipoprotein (LDL) receptors $[17,18]$. This upregulation allows cancer cells to increase uptake of cholesterol-rich LDL particles. This observation led to the proposal that using LDL as a carrier could concentrate anti-cancer drugs in malignant cells and tissues. This hypothesis was successfully demonstrated in several different cancer types $[19,20]$. However, the difficulties associated with incorporating drugs into LDL particles and isolating lipoproteins from human plasma have impeded the development of LDLbased chemotherapy for cancer patients. These difficulties were addressed with the development of nanoemulsions [21].

Practical use of the LDL receptor-mediated endocytic pathway was made possible by work from Maranhão et al. [22, 23]. They prepared artificial, lipid core nanoparticles with a composition that resembled LDL. When injected into the bloodstream, these nanoparticles could acquire apolipoprotein (apo) E, when they came into contact with native plasma lipoproteins. These apoE-carrying nanoparticles (LDE) could bind to LDL receptors through the apo E ligand, and thus, they were internalized into the cytoplasm. Furthermore, drugs associated with LDE could be concentrated inside cancer cells and tissues that expressed high LDL receptor levels, resulting in greater pharmacological activity and severalfold less drug toxicity [24-26].

Recently we have described a 7KC-containing nanoemulsion developed to provide an artificial nanoparticle suitable to study $7 \mathrm{KC}$ metabolism in lipoproteins [27]. This preparation (7KCLDE) was based on LDE composition and resembled LDL behavior. Here we tested the ability of 7KCLDE to cause cell death, to target tissues selectively and to decrease drug toxicity. The preliminary results from in vitro and in vivo experiments suggested that this novel preparation showed promising potential for future use in cancer chemotherapy.

\section{RESULTS}

\section{In vitro studies}

\section{KCLDE uptake by LDL-receptor}

Figure 1 shows the results of the competition experiments. There was a small uptake of 7KCLDE by melanoma cells incubated at $4^{\circ} \mathrm{C}$, indicating that the receptor-independent pathway is less important. Uptake of 7KCLDE by cells incubated at $37^{\circ} \mathrm{C}$ was increasingly reduced by co-incubating with increasing amounts of native LDL. This finding strongly suggested that LDL and $7 \mathrm{KCLDE}$ were taken up by the same cell receptor mechanisms.

\section{In vitro effects of 7KCLDE on B16F10 cell growth and death}

In an initial set of experiments, B16F10 cells were grown in the presence of $7 \mathrm{KC}$ or cholesterol, both diluted in ethanol, over a period of three days (Figure 2). Cells treated with $100 \mu \mathrm{M}$ cholesterol showed the same doubling times as cells treated with ethanol alone (control) (Figure 2A). In contrast, cells treated with $100 \mu \mathrm{M} 7 \mathrm{KC}$ showed growth arrest, and cell death (Figure 2A). Flow cytometric analysis of PI-stained cells treated with $7 \mathrm{KC}$ showed high proportions of hypodiploid cells $(>20 \%)$ (Figure 2C). Next, melanoma cells treated with 7KCLDE were compared to two controls: LDE alone and LDE with an additional amount of cholesterol that corresponded to the concentration of $7 \mathrm{KC}$ (CholLDE). The two controls showed the same growth rates (Figure 2B). In contrast, 
cells treated with 7KCLDE showed growth arrest (Figure 2B) but, interestingly, no increase in the cell death rates were observed within the first $48 \mathrm{~h}$, based on the proportions of hypodiploid cells (Figure 2D). After $48 \mathrm{~h}$, cell death increased, but the rate was much lower than that observed with $7 \mathrm{KC}$ alone. Treatment with $7 \mathrm{KC}$ led to a decrease of cells in the proliferative phases of the cell cycle while treatment with 7KCLDE induced decrease of percentage of cells in $\mathrm{G}_{0} / \mathrm{G}_{1}$ (Supplementary Table 1). Thus, although a high concentration of $7 \mathrm{KC}$ induced cell death, as expected, 7KCLDE did not, at least at the same concentration.

Figure 3 shows that treatment with $7 \mathrm{KCLDE}$ for $24 \mathrm{~h}$ led to the dissipation of the mitochondrial transmembrane potential, measured as the loss of JC-1 aggregates. A significant increase in the fluorescence intensity of JC-1 aggregates was also observed in cells with an intact transmembrane potential (Figure 3D). This increase was previously ascribed to mitochondrial hyperpolarization [28], which precedes depolarization (Figure 3E). This phenomenon has been associated with mitochondrial release of cytochrome $\mathrm{c}$, and it might elicit cell death via the apoptosis pathway.

The morphology of surviving cells led us to further explore the action of 7KCLDE. Upon $24 \mathrm{~h}$ of exposure to $7 \mathrm{KC}$, the cells lost cytoplasm and began to detach from the plastic dish (Figure 4B). After treatment with 7KCLDE (Figure 4D), but not LDE (data not shown) or CholLDE (Figure 4C), melanoma cells shifted from the epithelioid (Figure 4A) to a fibroblastoid (Figure 4D) morphotype. Spindle-shaped cells became increasingly abundant in cell cultures treated with 7KCLDE. This change in morphology was associated with increased polymerization of the actin cytoskeleton, evidenced with phalloidin staining (Figure 4D). Interestingly, the changes observed were not associated with the formation of typical stress fibers. Some binucleated cells were also found among 7KCLDE-treated melanoma cells. This finding prompted us to investigate whether cell growth arrest and altered cytoskeleton organization were associated with impaired cytokinesis.

Figure $5 \mathrm{~A}$ shows that long exposure to $7 \mathrm{KCLDE}$ caused significant increases in the number of polyploid cells, and significant reductions in the proportions of cells in $\mathrm{G}_{\mathrm{o}} / \mathrm{G}_{1}$ phase. The flow cytometry results suggested that the increase in polyploid cells might be due to DNA uptake; i.e., the surviving cells might phagocytose the dying cells, which would account for the elevated DNA content. Alternatively, polyploid cells could occur when cells replicated their DNA, but then, were arrested in mitosis. To investigate this mechanism, we pulse-labeled B16F10 cells with the lipophilic fluorophore, $\mathrm{DiIC}_{18}$, and chased it for three consecutive days in the experimental conditions shown in Figure 5B. As cells divided, the lipophylic dye was distributed randomly between the daughter cells. Thus, with normal cytokinesis, a progressive decline is observed in the mean fluorescence intensity per cell. Treating B16F10 cells with either LDE or CholLDE did not impair cytokinesis (Figure 5B). However, when cells were treated with $7 \mathrm{KCLDE}$, the DiIC $_{18}$-pulsed cells exhibited high fluorescence intensity over the entire assay period. This finding indicated that 7KCLDE strongly interfered with mitosis, and growth arrest resulted. Therefore, 7KCLDE has cytostatic action. The discrete, but significant, increase in the fluorescence intensity on day 3 (Figure 5B) suggested that 7KCLDEtreated cells might take up the dye released from dying cells.

Ultrastructural analyses of cells treated with CholLDE (Figure 6A) and 7KCLDE (Figure 6BD) allowed us to characterize the subcellular effects of $7 \mathrm{KCLDE}$. No alterations were observed when B16F10 cells were treated with CholLDE (Figure 6A). However, 7KCLDE-treated B16F10 cells underwent a morphotypic conversion to a spindle-shaped cell (Figure 6B). We commonly found disruptions of the

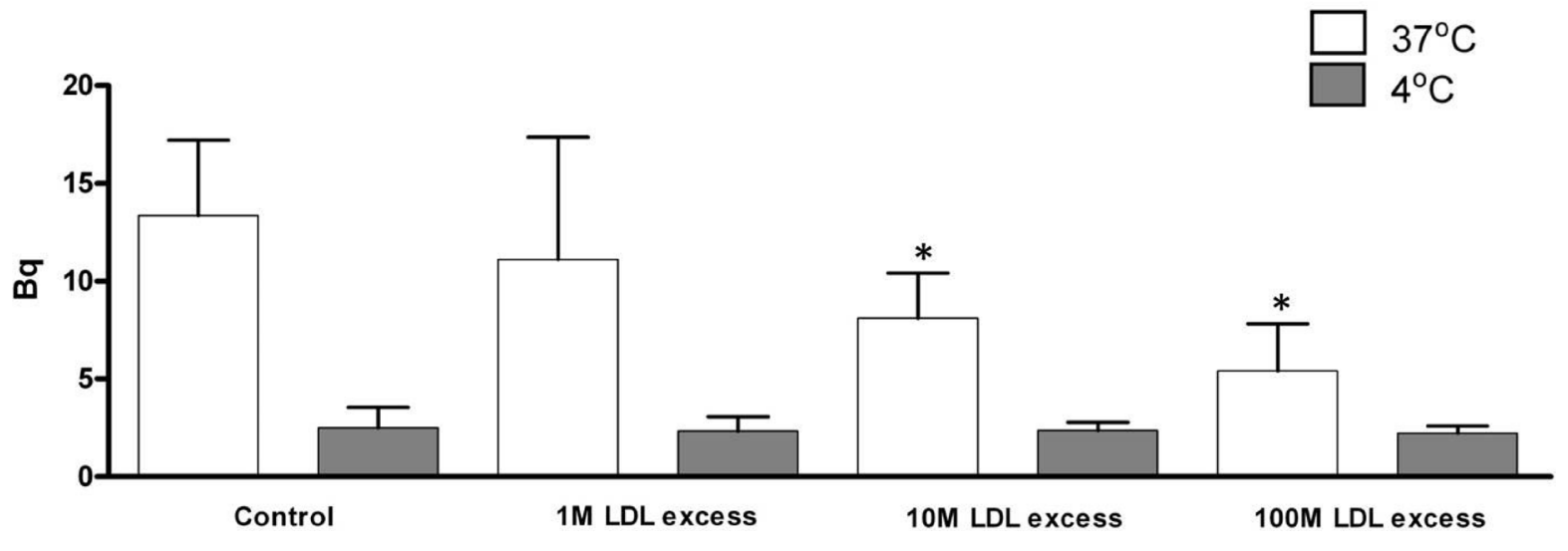

Figure 1: Uptake of 7KCLDE in the presence of native LDL. B16F10 cells were incubated with $75 \mu \mathrm{M}\left[{ }^{3} \mathrm{H}\right] 7 \mathrm{KC} /\left[{ }^{14} \mathrm{C}\right] \mathrm{cholesterol-}$ containing $7 \mathrm{KCLDE}$ and HDL $(43 \mu \mathrm{g} / \mathrm{mL})$, in either the absence or presence of LDL (1:1 up to 100:1 molar ratios of LDL:LDE) in serumfree medium for $4 \mathrm{~h}$. The amount of radiolabeled material in cell lysates was determined with a LKB beta-counter. Each bar represents the mean \pm SD of 6 independent experiments performed in triplicate. 
cytoplasm and formation of concentric structures (Figure 6B, 6C). Note that the nuclei changed shape, according to the impedance caused by these lamellar structures; this finding suggested that the structures were associated with a rigid material within the cytoplasm of $7 \mathrm{KCLDE}$-treated cells. Bundles of microfilaments were found scattered in the cytoplasm (Figure 6D); this ultrastructural finding seemed to be related to the increase in actin fiber polymerization (Figure 4D). Finally, we found multilayered vacuoles that resembled autophagolysosomes in cells treated with $7 \mathrm{KCLDE}$ (Figure 6D).

Autophagolysosomes are acidic compartments that can be measured with flow cytometry, based on a property of the fluorophore, acridine orange. Acridine orange stains acidic compartments in organelles with bright orange fluorescence. In control cells, $2.56 \pm 0.26 \%$ of cells harbored acidic compartments. However, with 7KCLDE treatment, $6.37 \pm 1.39 \%(p<0.05)$ of cells harbored acidic vacuoles (Figure 7 ). These results were confirmed with the fluorophore, monodansylcadaverine, which stains autophagic vacuoles (data not shown).

\section{In vivo studies}

Plasma kinetics of 7KCLDE in healthy mice with melanoma implants

Following a single intravenous bolus injection of double-labeled $7 \mathrm{KCLDE}$, both ${ }^{3} \mathrm{H}-7 \mathrm{KC}$ and free
${ }^{14} \mathrm{C}$-cholesterol levels progressively declined in the plasma of control mice (Supplementary Figure 1A). A similar decay curve was observed in mice with melanoma implants (Supplementary Figure 1B).

\section{Tumor uptake of 7KCLDE}

In control animals, the 7KCLDE complex was taken up mainly by the liver, and, to a much lesser extent, by the adrenal glands, demonstrated by measurements of ${ }^{3} \mathrm{H}-7 \mathrm{KC}$ and free ${ }^{14} \mathrm{C}$-cholesterol levels (data not shown). In animals with tumors (Supplementary Figure 2), liver uptake was higher than in controls. However, the tumors also took up 7KCLDE, and tumor content accumulated over time.

\section{Melanoma-bearing mice treated with $7 \mathrm{KCLDE}$}

Melanoma-bearing mice were treated daily with intraperitoneal injections of 7KCLDE, LDE alone, or saline (control). Hematological and biochemical analyses showed that 7KCLDE had no apparent toxicity. No toxicity was detected on hemograms, myelograms, or spleen cellularity analyses (data not shown), at the administered doses. This finding suggested that this nanoemulsion was well tolerated.

Figure 8 shows typical histological images of tumor tissues. The histological analysis of tumors showed that tumors from $7 \mathrm{KCLDE}$-treated mice had larger necrotic areas $(53.4 \pm 7.8 \%)$ than tumors from control mice (18.0 $\pm 5.54 \%, p<0.001$ ) (Figure 8C, 8D). We also estimated
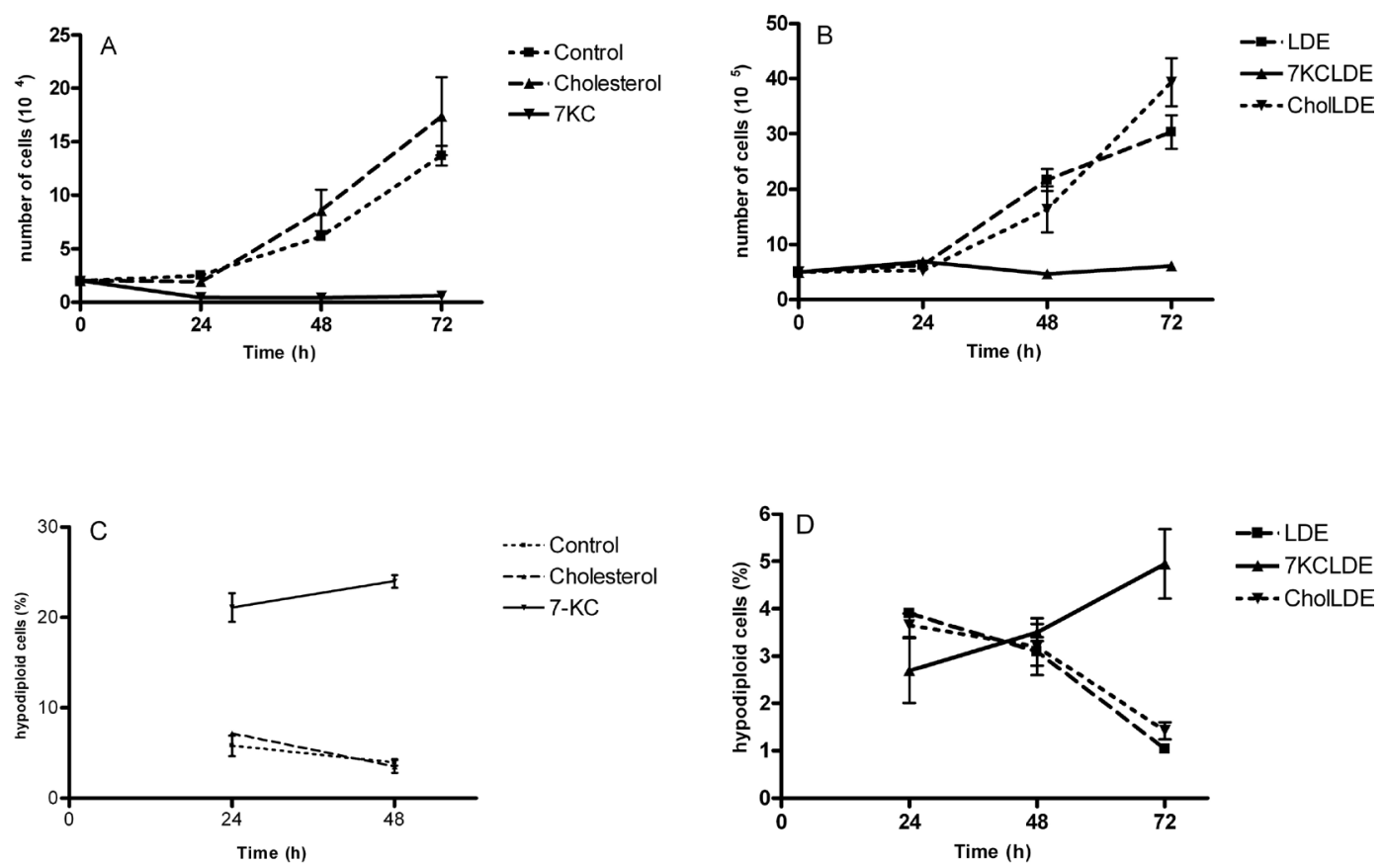

Figure 2: Cytotoxicity of 7KCLDE to B16F10 cells. B16F10 cells were incubated with cholesterol (chol), LDE, CholLDE , or $7 \mathrm{KCLDE}$ for 1 to 3 days. (A, B) Cell viability was determined with trypan blue exclusion. (C, D) Cell cycle analyses were performed with flow cytometry; propidium iodide was used as a DNA-intercalating agent. Each point represents the mean \pm SD of 6 independent assays performed in triplicate. 
the tumor vascular area with Verhoeff impregnation. The results showed that tumors from mice treated with $7 \mathrm{KCLDE}$ had smaller vascular areas $(4.95 \pm 4.27 \%)$ than tumors from control mice $(9.8 \pm 2.76 \%$; Figure $8 \mathrm{~B})$. After 12 days of treatment, we observed a significant reduction in the tumor volume, promoted by $7 \mathrm{KCLDE}$ (Figure 9A).

$7 \mathrm{KCLDE}$ treatment also affected mouse survival rates. Mice treated with $7 \mathrm{KCLDE}$ had a higher mean survival rate (Figure 9B) than mice treated with control (saline) or LDE solutions. Generally, animals treated with $7 \mathrm{KCLDE}$ lived up to 15 days longer than mice in other treatment groups.

\section{DISCUSSION}

It is well known that bioactive lipids promote activation or regulation of several cellular processes [29$31]$, such as cell growth, proliferation, differentiation, and cell death [32, 33]. Among these compounds, oxysterols are potent, biologically active molecules. They are involved in a variety of functions, including the inhibition of cell proliferation and the promotion of cell death [34, 35]. Among all cholesterol oxides, $7 \mathrm{KC}$ has been extensively studied. When added to cell cultures, $7 \mathrm{KC}$ led to the formation of ROS, which
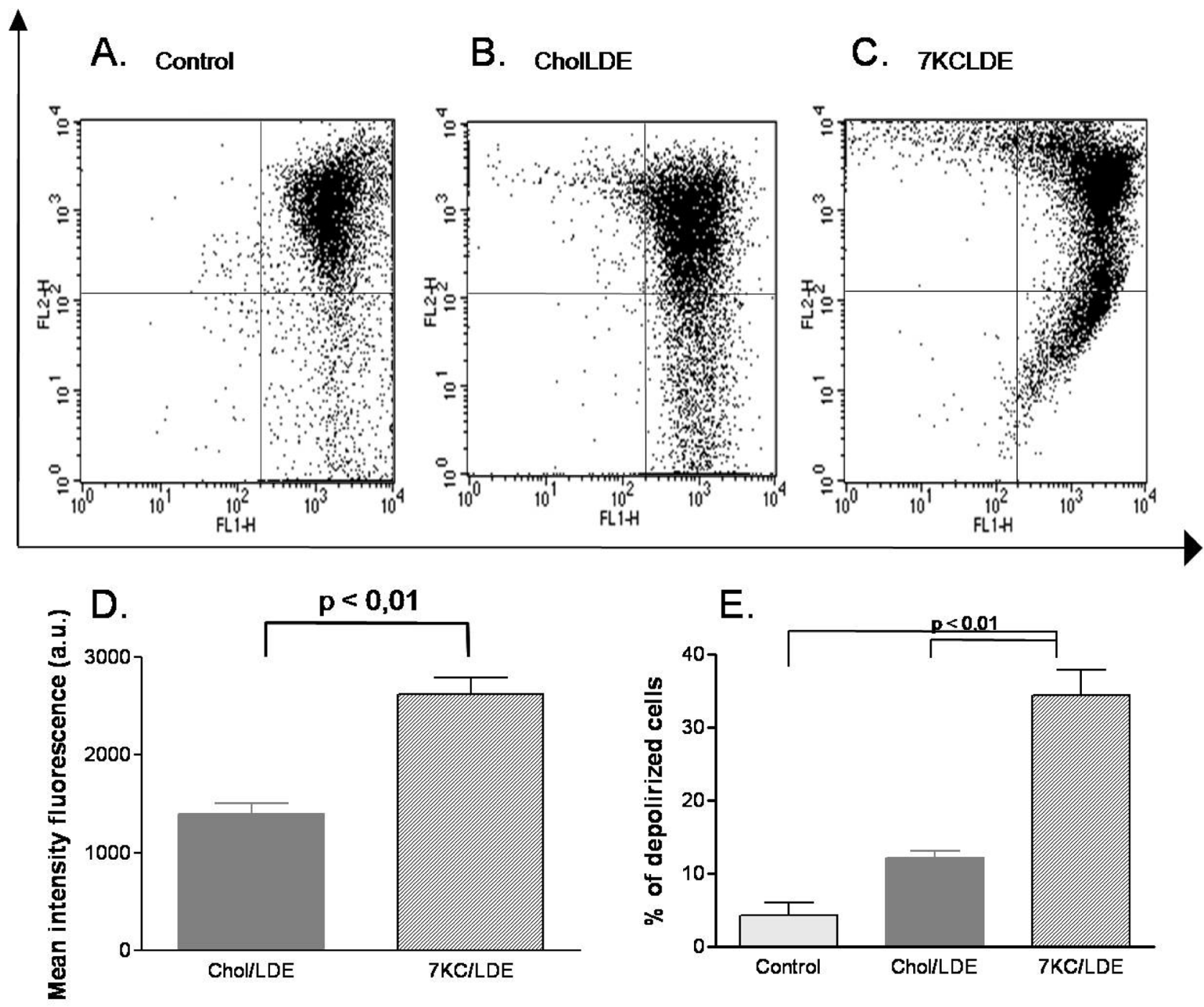

Figure 3: Effects of $7 \mathrm{KCLDE}$ on mitochondrial transmembrane potential $\left(\Delta \mathrm{Y}_{\mathrm{m}}\right)$ in $\mathrm{B} 16 \mathrm{~F} 10$ cells. B16F10 cells were incubated with LDE or $7 \mathrm{KCLDE}$ for $24 \mathrm{~h}$, and the $\Delta \mathrm{Y}_{\mathrm{m}}$ was determined by staining with JC-1 (see Materials and Methods). Plots (A-C) represent the distribution of JC-1 aggregates as a function of JC-1 monomers. The $\Delta \mathrm{Y}_{\mathrm{m}}$ is characterized by a reduction in JC-1 aggregates. (D) The mean fluorescence intensity of the upper right panel of each dot plot was quantified. The values represent the proportions of cells that harbored JC-1 concentrated in the mitochondria, which caused aggregate formation. Treatment of cells with 7KCLDE led to a significant increase in the mean fluorescence intensity of JC-1 aggregates. (E) Quantification of cells with dissipation of the mitochondrial transmembrane potential. The data indicate that $7 \mathrm{KCLDE}$ caused a loss of $\Delta \mathrm{Y}_{\mathrm{m}}$ in around $30 \%$ of cells after a $24-\mathrm{h}$ treatment. Bars represent the mean $\pm \mathrm{SD}$ of 6 independent experiments performed in triplicate. ${ }^{*} p<0.05 ;{ }^{* *} p<0.01$; a.u. $=$ arbitrary unit. 
induced lipid peroxidation and protein oxidation [36]. The protein modifications included both reversible and irreversible oxidation of sulfhydryl (-SH) groups found in proteins of essential cellular pathways, such as glutathione reductase, calcium ATPases, and actin [36]. These modifications were ultimately associated with cell death, either through classical apoptosis or by induction of autophagy. In fact, $7 \mathrm{KC}$ induced a particular mode of cell death, termed oxiapoptophagy, which simultaneously involved oxidation, apoptosis, and autophagy [8, 36]. The cytotoxic effects of $7 \mathrm{KC}$ have been demonstrated in both nontumorigenic and tumorigenic cell lines [11, 12, 37-41]. Here, we extended those observations to murine melanoma cells. Furthermore, we devised a strategy for delivering $7 \mathrm{KC}$ to cells in a controlled manner.

Several drug delivery systems that carry anti-cancer chemotherapeutic agents have been tested in patients with cancer, including liposomes, lipid core nanoparticles, albumin nanoparticles, and polymeric nanoparticles.
Natural and synthetic HDL and LDL particles have also been explored for their use as vehicle for drug delivery [42-44]. Nevertheless, in a literature review of the past 10 years, it was reported that only $0.7 \%$ of administered nanoparticles was delivered to solid tumors [45]. LDE consists of a core of cholesteryl esters with residual triglycerides, surrounded by phosphatidylcholine and some unesterified cholesterol. LDE was probably the first non-liposomal drug delivery system that showed clear drug targeting properties [23]. Moreover, the toxicity of chemotherapeutic agents declined more intensely when associated with LDE [46, 47].

In this study, we intend to create an anti-cancer agent by adding an oxidized cholesterol derivative, 7-ketocholesterol, to LDE components. In melanoma cells, $7 \mathrm{KC}$ increased cell death, evidenced by the percentage of hypodiploid cells. However, upon emulsification with LDE, the percentage of hypodiploid cells was reduced. This could be explained, at least in part, by the fact that
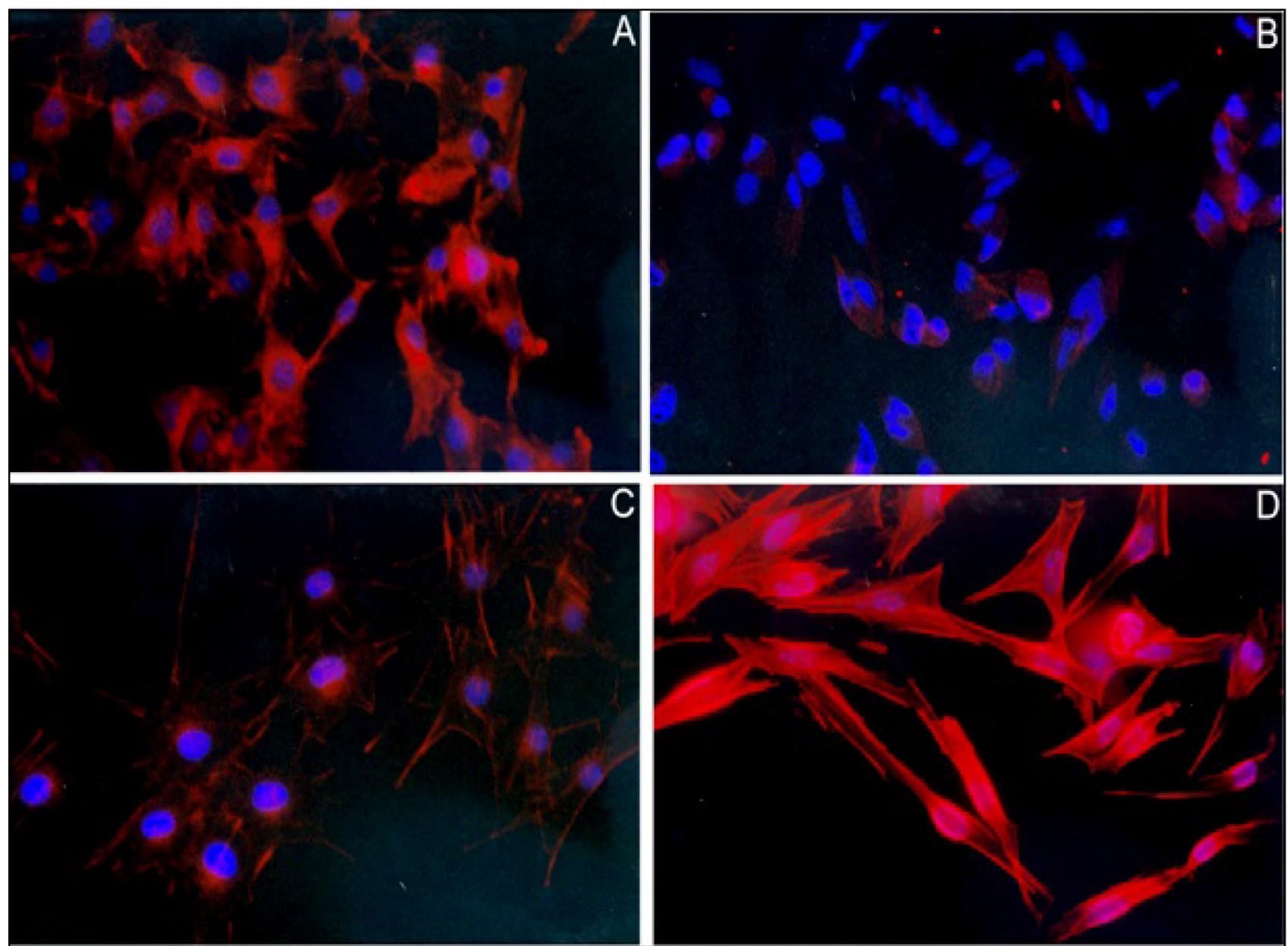

Figure 4: Effects of 7KCLDE on the formation of actin fibers in B16F10 melanoma cells. B16F10 cells were cultured in the presence or absence of the indicated LDE emulsions for $24 \mathrm{~h}$. (A) Under control conditions, melanoma cells were dendritic in shape. (B) Cells exposed to $7 \mathrm{KC}(75 \mu \mathrm{M})$ died, due to a loss of cytoplasm and detachment. (C) Cells incubated with LDE did not change in morphology. (D) Cells exposed to $7 \mathrm{KCLDE}(75 \mu \mathrm{M}$ of $7 \mathrm{KC})$ shifted in shape towards a fibroblastoid phenotype. This morphotypic change was associated with the formation of actin fibers, which was visualized with phalloidin-TRITC. Nuclei were visualized with DAPI. The nuclear shape changed with the phenotypic shift. Photomicrographs show representative, high power fields (magnification, $\times 400$ ). 
some deleterious effects of oxysterols in vitro can be diminished when they are combined with cholesterol or even with other oxysterols [48, 49]. 7KCLDE induced cell death by dissipating mitochondrial transmembrane potential and by causing DNA cleavage and acidic vacuole accumulation. Moreover, the acidic vacuoles were consistent with autophagolysosomes, based on the ultrastructural analysis (presence of myelin figures). Therefore, 7KCLDE induced pathways involved in both apoptosis and autophagy, consistent with descriptions of cells exposed to $7 \mathrm{KC}[11,36,50]$. In our model, $\mathrm{J}$-aggregates accumulated in the mitochondria of a large proportion of cells. This finding was previously described as indicative of mitochondrial hyperpolarization, which precedes dissipation of the transmembrane potential in apoptosis [28].

Therefore, 7KCLDE induced cell death in a significant fraction of melanoma cells, but it showed less potency than $7 \mathrm{KC}$ alone. The surviving cells invariably showed cytoskeletal rearrangements and were growtharrested. The 7KCLDE cytostatic effect was not associated with arrest in the $\mathrm{G}_{0} / \mathrm{G}_{1}$ phases. In fact, DNA replication seemed to occur normally, based on the increasing frequency of polyploid cells. Disruption of cytoskeletal dynamics, as indicated by the increased polymerization of the actin cytoskeleton, may have impaired cytokinesis, which in turn, led to the emergence of a polyploid cell population. Increased actin polymerization was not related to the formation of stress fibers, suggesting that 7KCLDE induced an aggregation of actin fibers, rather than controlled polymerization. The presence of these aggregates within the cytoplasm was related to changes in nuclear morphology and the generation of concentric figures found within the cytoplasm at the ultrastructural level. The cytostatic effects of 7KCLDE were long-lasting, and they were not reversed when the emulsion was washed out.

The polymerization of actin is a laborious process that involves many proteins [51-53]. These proteins cleave, transport, and anchor actin to the plasma membrane. Some proteins act indirectly; for example, p38 MAP kinase modulates the reorganization and phosphorylation of heat shock protein 27 , an important protein involved in oxidative stress-induced alterations in the cytoskeleton [28]. The cytoskeletal changes elicited by $7 \mathrm{KC}$ may be associated with the production of ROS $[54,55]$, which may activate MAP kinase and lead to actin polymerization. Moreover, it has been demonstrated that oxidative stress can disrupt the microfilaments of the cytoskeleton $[55,56]$.

When injected intraperitoneally into melanomabearing $\mathrm{C} 57 \mathrm{bl} / 6 \mathrm{~J}$ mice, radioactive $7 \mathrm{KCLDE}$ was mainly found in the liver and in the tumor. Moreover, the tumor concentration increased over time. We found in these preliminary studies that $7 \mathrm{KCLDE}$ controlled tumor growth in vivo, which suggested that the in vitro effects of
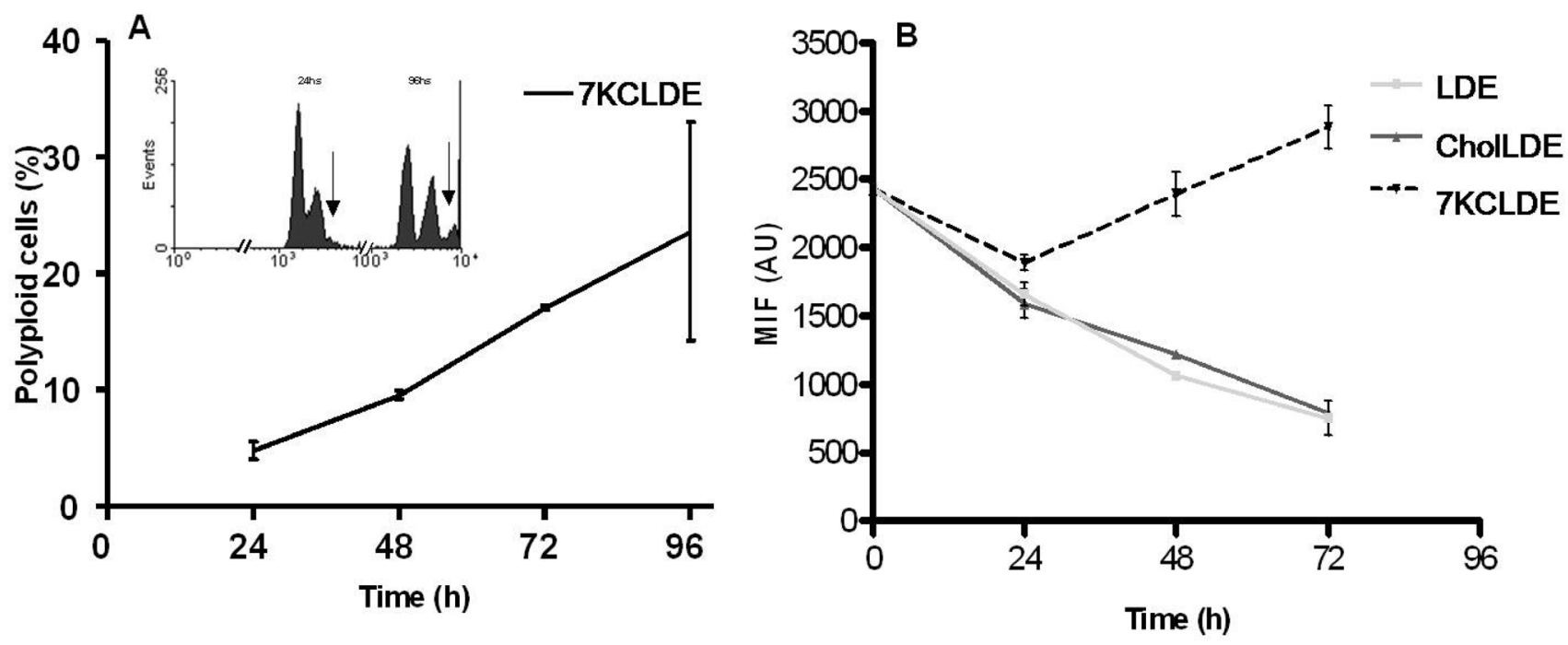

Figure 5: LDE7KC-induced polyploidy, associated with impaired cytokinesis. B16F10 cells were incubated with LDE, CholLDE, or 7KCLDE for 1 to 4 days. Media containing the different emulsions were replenished every day. DNA content was analyzed by detecting propidium iodide with flow cytometry. (A) Emergence of a polyploid population (arrows) after 4 days of treatment with $7 \mathrm{KCLDE}$. The fraction of polyploid cells increased progressively during treatment with 7KCLDE, as indicated. Points represent the mean $\pm \mathrm{SD}$ of 5 independent assays performed in triplicate. No polyploid population was observed when cells were treated with either LDE or CholLDE (data not shown). (B) The separation of daughter cells after mitosis. Cells were pulse-labeled with the lipophilic dye, DiIC ${ }_{18}$, and chased for 1 to 3 days. Distribution of the fluorescent dye in post-mitotic cells was analyzed with flow cytometry. In both LDE-treated and CholLDE-treated cells, cell division was followed by a decline in the amount of fluorescent dye/cell. Cells treated with 7KCLDE did not lose fluorescent dye, suggesting that cytokinesis was halted. Each point represents the mean $\pm \mathrm{SD}$ of 5 independent assays performed in triplicate. MIF: Mean Intensity Fluorescence. 
7KCLDE may also operate in vivo. Furthermore, 7KCLDE did not cause any overt adverse reactions in treated mice. Our biochemical analyses included AST and ALT hepatic enzyme levels, and hematological analyses. These findings warrant more pharmacodynamic and preclinical studies of 7KCLDE.

Strikingly, the 7KCLDE-treated mice 50\% survival was roughly the double (16 days) than untreated animals (8 days) and higher than LDE-treated animals (12 days).
In summary, this study showed that it was possible to create a 7KC-based bioactive nanoparticle with potential applications as an antiproliferative agent. Although much more pre-clinical studies are needed, including the testing of other cell lines and efficacy of different doses in terms of melanoma (and other tumors) progression and survival rate, the preliminary results strongly suggest that this novel 7KCLDE nanoparticle has promising potential for cancer therapy applications.

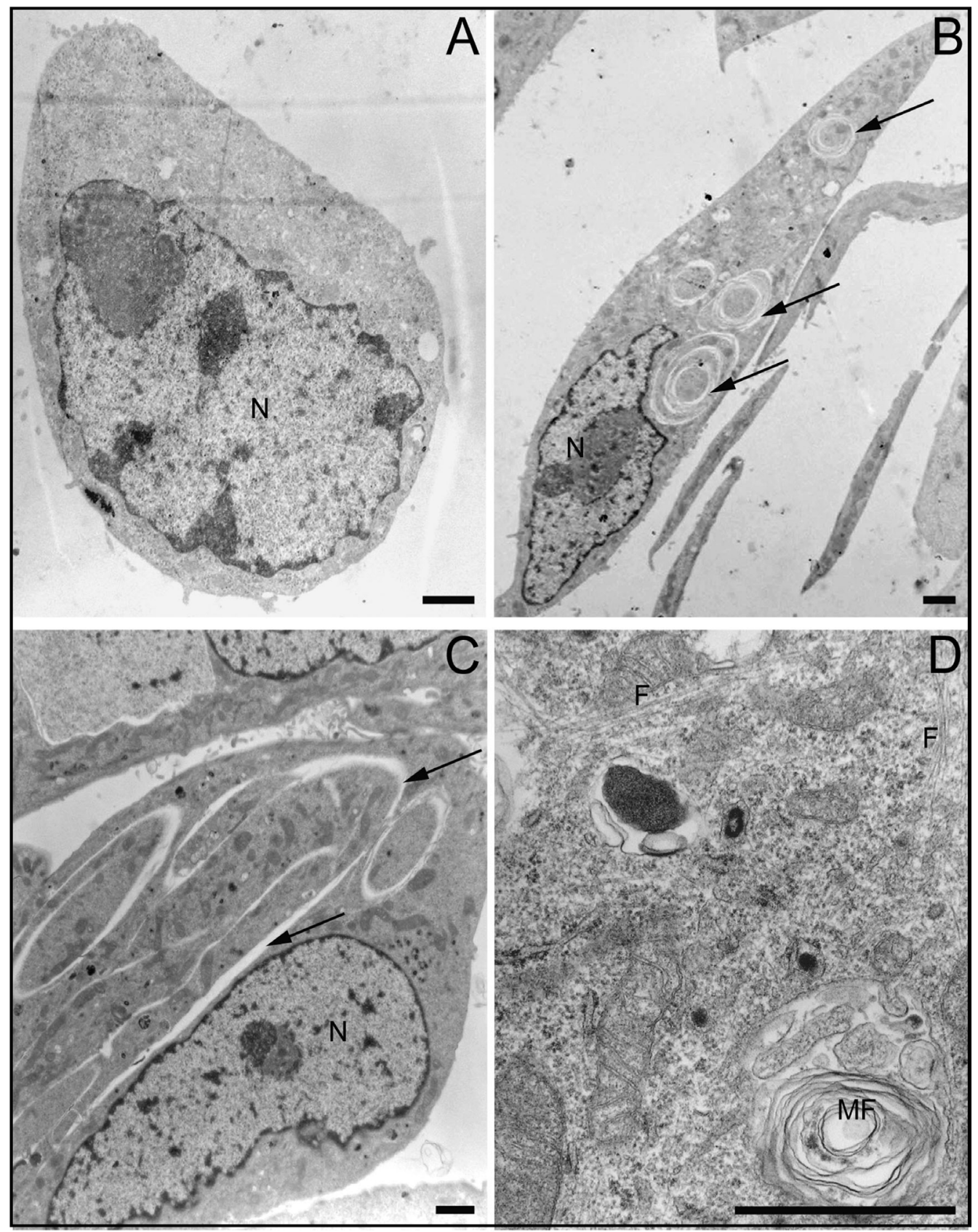

Figure 6: Ultrastructural changes in LDE7KC-treated cells. Micrographs show (A) CholLDE-treated cell, and (B-D) 7KCLDE-treated cells. B16F10 melanoma cells shifted towards a fibroblastoid morphotype. (B, C) Nuclei (N) of 7KCLDE cells displayed morphological changes consistent with changes that led to the generation of structural ruptures in the cytoplasm (arrows). (D) Micrograph shows bundles of microfilaments (F) and autophagolysosomes (MF, myelin figures) observed after treatment with 7KCLDE. Scale bars indicate $1 \mu \mathrm{m}$. 


\section{MATERIALS AND METHODS}

\section{Materials}

Egg phosphatidylcholine, triolein, cholesteryl oleate, cholesterol, and 7KC were purchased from Sigma-Aldrich (St Louis, MO, USA). Lipids were 98\% pure, determined with thin layer chromatography. $\left[{ }^{14} \mathrm{C}\right]$-cholesterol (specific activity: $49 \mathrm{Ci} / \mathrm{mmol}$ ) was acquired from Amersham (Little Chalfont, UK); [1,2,6 $\left.{ }^{3} \mathrm{H}\right]-7$-ketocholesterol (5-cholesten$3 \beta$-ol-7-one, specific activity: $50 \mathrm{Ci} / \mathrm{mmol}$ ) was acquired from American Radiolabeled Chemicals (St Louis, MO, USA), $99 \%$ pure. Cell culture materials were purchased from Invitrogen (Carlsbad, CA, USA). All other materials were from Sigma-Aldrich.

\section{Ethics statement}

The investigation has been conducted in accordance with ethical standards and national and international guidelines. The protocol of the study was approved by the Ethics Committee of the University of São Paulo Medical School (CAPEPesq 391/10).

\section{Preparation of 7KC-containing nanoparticles}

7KCLDE was prepared as described [27] based on the method for LDE preparation [22, 23]. Briefly, a lipid mixture $(5.0 \mathrm{mg} 7 \mathrm{KC}, 40 \mathrm{mg}$ cholesteryl oleate, $20 \mathrm{mg}$ egg phosphatidylcholine, $1.0 \mathrm{mg}$ triolein, and $0.5 \mathrm{mg}$ cholesterol in aqueous medium) was exposed to ultrasonic irradiation. Previous results showed that $5.0 \mathrm{mg}$ $7 \mathrm{KC}$ would be most appropriate for the experiments [27]. $\left[{ }^{3} \mathrm{H}\right]-7 \mathrm{KC}$ was added to each nanoemulsion preparation to enable evaluation of the amount of incorporated $7 \mathrm{KC}$. When necessary, radioactively labeled lipids $\left(\left[{ }^{3} \mathrm{H}\right]-7 \mathrm{KC}\right.$ and $\left.{ }^{14 \mathrm{C}}\right]$-cholesterol, $9 \times 10^{6} \mathrm{cpm}$ each) were added to the lipid mixtures, as indicated in the experimental protocols. Next, a two-step ultracentrifugation procedure was performed. The resulting $7 \mathrm{KCLDE}$ samples were
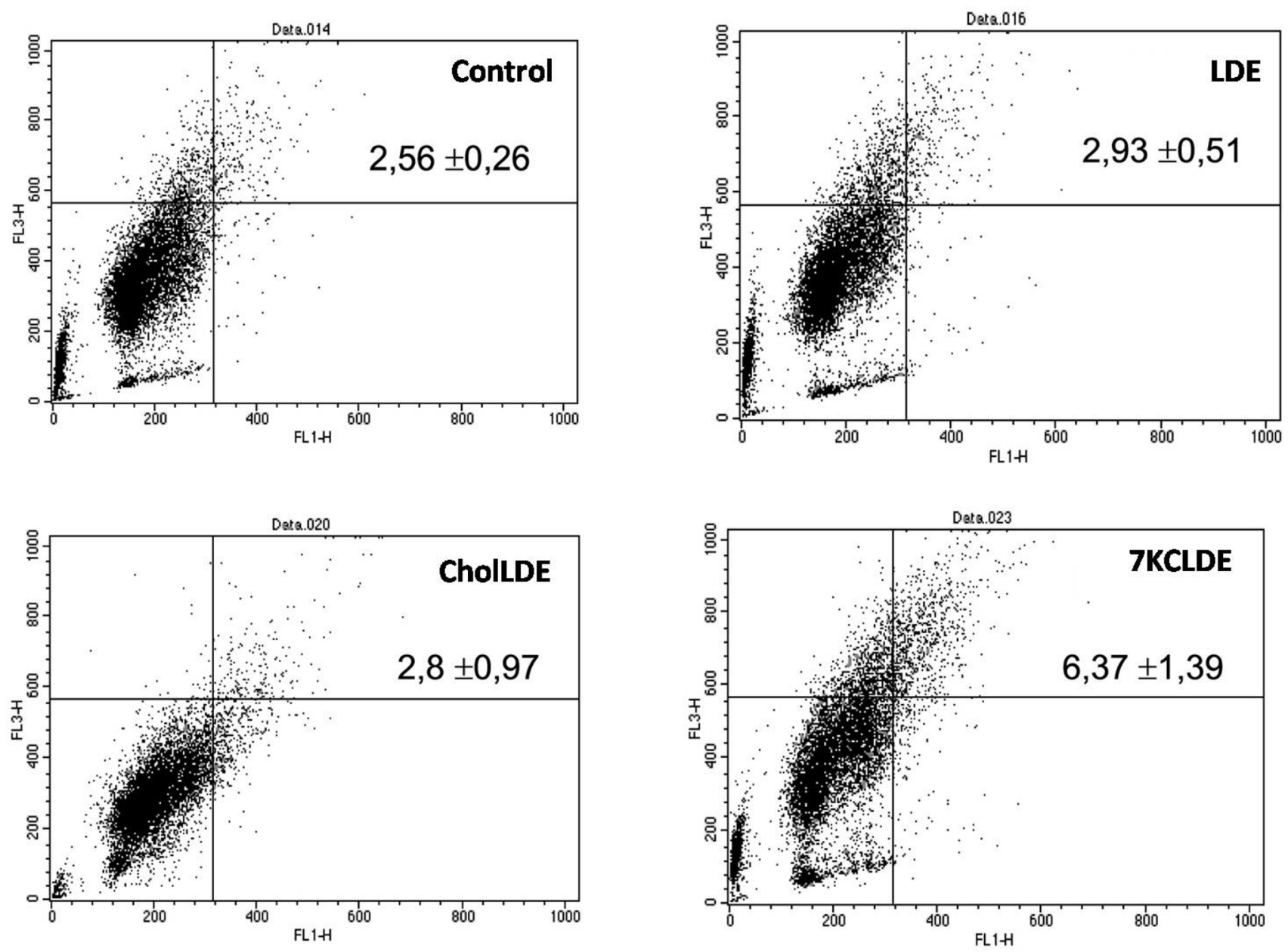

Figure 7: Acidic vacuole accumulation in B16F10 cells treated with 7KCLDE. Melanoma cells were incubated with the indicated emulsions for $24 \mathrm{~h}$ and treated with acridine orange, which stains acidic compartments in bright red fluorescence. The upper right panels of flow cytometry dot plots represent cells with acidic compartments. Numbers indicate the relative frequency \pm SD of a representative experiment performed in triplicate. 7KCLDE treatment increased $(p<0.05)$ cells harbored acidic vacuoles. 
dialyzed against a saline solution and sterilized by passing through a $0.22 \mu \mathrm{m}$ filter. Control preparations were made without $7 \mathrm{KC}(\mathrm{LDE})$ or by replacing $7 \mathrm{KC}$ for $5.0 \mathrm{mg}$ free cholesterol to the lipid mixture (CholLDE). The particle sizes in the different preparations were determined with laser light scattering (Zeta Potential Analyzer, Brookhaven

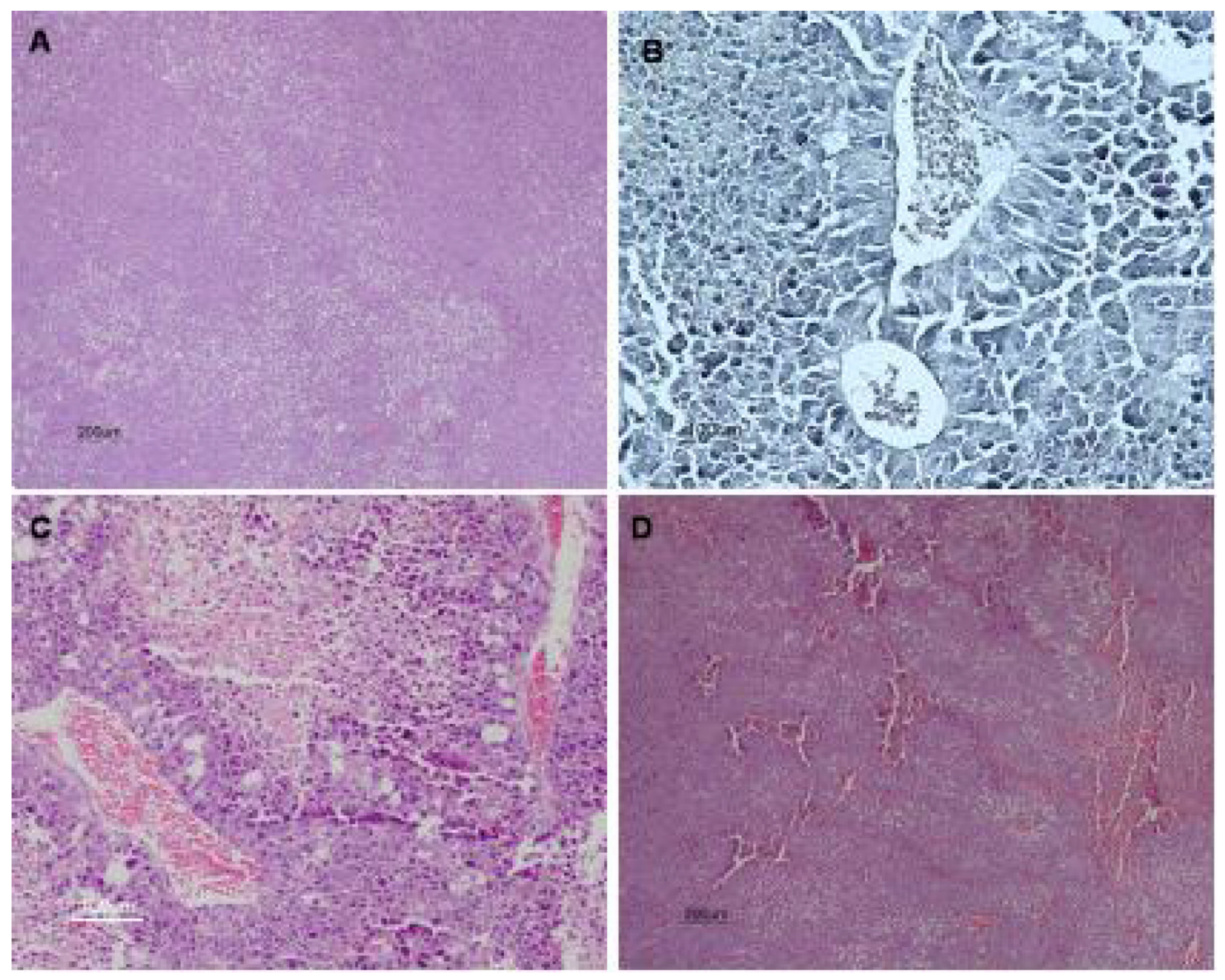

Figure 8: Histological analysis of melanoma tumors. Ten days after injection of $5 \times 10^{4} \mathrm{~B} 16 \mathrm{~F} 10$ cells rats were treated with $7 \mathrm{KCLDE}(156 \mathrm{mM}, 100 \mu \mathrm{L}$ volume IP) for other 10 days $(n=7)$. Animals were then sacrificed and tumors examined. Microscopic images show various tumor regions: (A) tumor (H\&E staining, $\times 40)$; (B) blood vessels (Verhoeff staining, $\times 200)$; and (C, D) necrotic areas (H\&E staining, C: $\times 100, \mathrm{D}: \times 40$ )

A

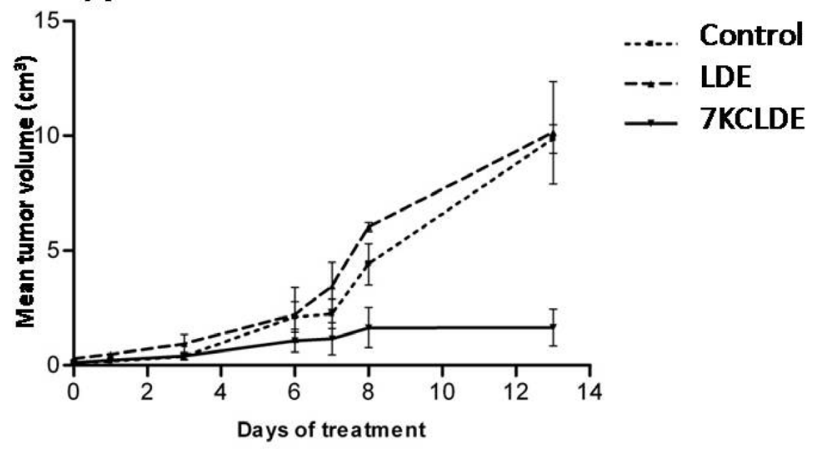

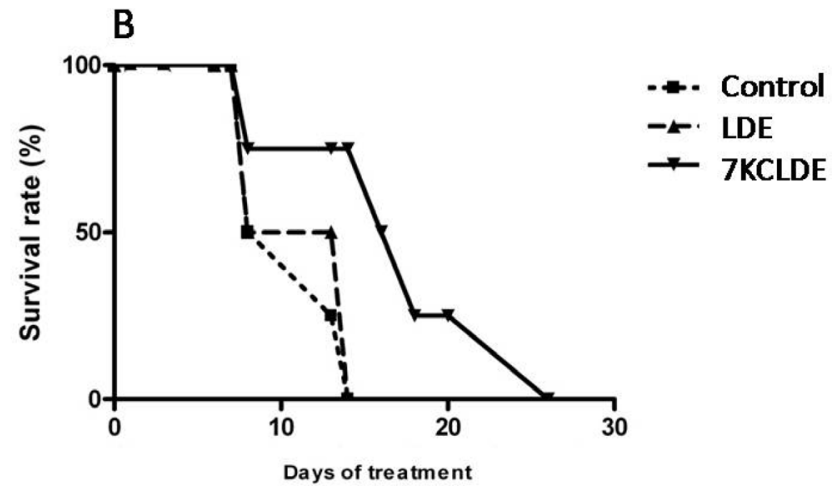

Figure 9: Effects of 7KCLDE in vivo. (A) 7KCLDE reduced tumor volume. C57b1/6 mice were injected with B16F10 melanoma cells. After 10 days, mice were randomly divided into three groups to receive treatment with 7KCLDE $(n=8)$, LDE, $(n=7)$, or saline (control, $n=5$ ) for 10 consecutive days (see material and methods). A significant reduction in tumor volume was observed in mice that received daily injections of 7KCLDE. Results are the mean $\pm \mathrm{SD} ; p<0.05$ (One Way ANOVA). (B) 7KCLDE treatment increased animal survival. Plot shows the percentage of B16 melanoma-bearing mice that survived in response to 7KCLDE treatment. Treatment prolonged survival by up to 15 days ( $p<0.05$; Kaplan-Meier Survival Analysis). 
Instruments, Holtsville, NY). Preparations were used only when the nanoparticle diameters were in the range of 20$50 \mathrm{~nm}$, the same measured by the LDE alone and by native LDL. The nanoparticles were stable for at least one month, evidenced by visual inspection and by measuring the diameters with laser light scattering. Nevertheless, they were used within one week after preparation.

\section{Cell culture}

B16F10 melanoma cells were grown in RPMI 1640 medium supplemented with $10 \%$ fetal bovine serum (FBS) at $37^{\circ} \mathrm{C}$ in a humidified atmosphere containing $5 \% \mathrm{CO}_{2}$ [57]. After thawing [58], cells were seeded at an initial density of $2 \times 10^{4}$ cells $/ \mathrm{cm}^{2}$. Upon $80-90 \%$ confluence, cells were harvested with trypsin/EDTA. Culture contamination by mycoplasma was routinely tested by PCR. Cell viability was determined by Trypan Blue exclusion (Invitrogen, Carlsbad, CA), and by direct counting in a hemocytometer.

\section{Competition assay between human plasma LDL and $7 \mathrm{KCLDE}$}

To clarify whether 7KCLDE internalization depended on LDL receptors, we measured uptake of radiolabeled 7KCLDE in the presence of increasing concentrations of human plasma LDL. HDL was added at a constant concentration, as an apoE donor. These assays were performed at $4^{\circ} \mathrm{C}$ and $37^{\circ} \mathrm{C}$, as previously described [59]. Briefly, $2 \times 10^{4}$ cells were seeded into a 24-well plate and incubated with $75 \mu \mathrm{M}\left[{ }^{3} \mathrm{H}\right]-7 \mathrm{KC} /\left[{ }^{14} \mathrm{C}\right]-$ cholesterol-containing $7 \mathrm{KCLDE}$ and $43 \mu \mathrm{g} / \mathrm{mL} \mathrm{HDL}$, either in the absence or presence of different molar ratios of LDL/7KCLDE (1:1, 10:1, 100:1) in serum-free medium for $4 \mathrm{~h}$. Cells were then washed, harvested, and lysed. The amount of radiolabeled material in the cell lysates was determined in a LKB beta counter (Wallac, Turku, Finland).

\section{Cell cycle analysis}

Cell cycle analysis was determined with flow cytometry. After the indicated treatments, $2 \times 10^{6}$ cells were trypsinized, washed three times with PBS, fixed in $70 \%$ ethanol, and stained with propidium iodide (PI), as described [60]. All analyses were performed with a FACScalibur flow cytometer (Becton Dickinson, San Jose, CA). The red fluorescence signal from PI was detected through a 585/42-nm band-pass filter and measured on a linear scale of 1024 channels. For each sample, at least 10,000 events were acquired with CELLQuest software.

\section{Mitochondrial transmembrane potential}

To analyze mitochondrial transmembrane potential $(\triangle \Psi \mathrm{M})$ variations, we used carbocyanine dye JC-1, which accumulates in the mitochondrial matrix and forms J-aggregates. After the indicated treatments, cells were trypsinized and washed with PBS. Then, $10^{6}$ cells were incubated in medium with $200 \mathrm{nM} \mathrm{JC}-1$ at room temperature in the dark, in a humidified chamber for 15 min. Next, the cells were analyzed with flow cytometry. The emission at low membrane potential (green) was collected at $530 \mathrm{~nm}$ and the emission at high membrane potential (red) was collected at $585 \mathrm{~nm}$ [61]. All experiments were performed in triplicate. For each replica, data from 10,000 cells were acquired and analyzed with CELLQuest software.

\section{Supravital staining with DiIC $_{18}$}

Cells were labeled with DiIC $_{18}$, a supravital fluorochrome that can be used as a marker of cell division. Cells were seeded into 6-well plates $\left(2 \times 10^{6}\right.$ cells/well $)$ and $\mathrm{DiIC}_{18}$ was added in a 30-min pulse. Then, cells were washed with PBS. Both control and 7KCLDE-treated cells were then analyzed in sets of triplicates with flow cytometry, daily for three days. As cells divided, the amount of DiIC ${ }_{18}$ in each cell decreased geometrically; thus, the mean fluorescence intensity was correlated with the number of cell divisions.

\section{Morphological analysis}

Cells were seeded $\left(5 \times 10^{4}\right)$ onto coverlips and cultured in the presence of 7KCLDE. Cells were then fixed with $1 \%$ buffered paraformaldehyde for $5 \mathrm{~min}$ at room temperature, washed three times with a solution of $2 \%$ bovine serum albumin (BSA) in PBS, and finally, incubated with TRITC-labeled phalloidin (1:400 v/v in PBS), for $30 \mathrm{~min}$ at room temperature in the dark. The nuclei were stained with 4',6-diamidino-2-phenylindole (DAPI) at $1: 1000 \mathrm{v} / \mathrm{v}$ in PBS, for $5 \mathrm{~min}$ in the dark. Images were acquired with a digital camera connected to a Nikon Eclipse E600 fluorescence microscope.

\section{Electron microscopy}

After the indicated treatments, $2.0 \times 10^{7}$ cells were fixed in a $2 \%$ glutaraldehyde solution for $30 \mathrm{~min}$, postfixed in $2 \%$ osmium tetroxide for $10 \mathrm{~min}$, dehydrated with acetone, and embedded in Epon. Thin sections were cut and stained with uranyl acetate and lead citrate. The sections were examined with a JEOL 1010 electron microscope.

\section{Analysis of intracellular acidic compartments}

To analyze and quantify the presence of autophagic vacuoles, we added an autofluorescent compound, monodansylcadaverine (MDC, Sigma, St. Louis MO), which is a selective marker for autophagic vacuoles [62]. Cells $\left(5 \times 10^{4}\right)$ were seeded onto coverslips, incubated 
with $7 \mathrm{KCLDE}$, and then, incubated with $0.05 \mathrm{mM} \mathrm{MDC}$ in PBS at $37^{\circ} \mathrm{C}$ for $15 \mathrm{~min}$. Cells were then washed 3 times with PBS and immediately analyzed under a fluorescence microscope. Different set of cells were also treated with different nanoemulsions for $24 \mathrm{~h}$, and then were stained for $20 \mathrm{~min}$ at $37^{\circ} \mathrm{C}$ with acridine orange $(1 \mu \mathrm{g} / \mathrm{mL})$, which emits a bright red fluorescent light when concentrated within an acidic compartment. Stained cells were harvested with trypsin, resuspended in PBS, and analyzed with flow cytometry, with excitation at $488 \mathrm{~nm}$ with an argon laser.

\section{In vivo studies}

Melanoma xenografts were created in C57BL/6J mice by injecting subcutaneously $5 \times 10^{4}$ B16F10 melanoma cells into the left flank. Experiments were performed after tumors became palpable, 8-10 days after the injection.

\section{Plasma kinetics and biodistribution of double- labeled 7KCLDE}

7KCLDE (0.3 mg) was labeled with ${ }^{3} \mathrm{H}-7 \mathrm{KC}$ and free ${ }^{14} \mathrm{C}$-cholesterol. This double-labeled $7 \mathrm{KCLDE}$ was injected into mice as a single bolus delivered into the retro-orbital venous plexus (control, $n=7$; tumor, $n=7$ ). Blood samples were collected after 5 to $240 \mathrm{~min}$. Prior to radioactivity counting, plasma was separated from the blood samples with $3000 \times \mathrm{g}$ centrifugation for $15 \mathrm{~min}$.

After $4 \mathrm{~h}$, animals were killed by cervical dislocation, and samples from several organs were collected and maintained in saline solution prior to weighing. Lipid extraction was performed with chloroform: methanol $(2: 1, \mathrm{v} / \mathrm{v})$. Radioactivity was measured in a liquid scintillation solution.

\section{Tumor volume and rate of survival}

We tried to determine both, the maximum tolerated dose and LD50, with a single intraperitoneal injection of $7 \mathrm{KCLDE}$ at varying concentrations, from $2.5 \mathrm{mg} / \mathrm{kg}$ (78.125 mM) to $20 \mathrm{mg} / \mathrm{kg}(625 \mathrm{mM})$. Volumes ranged from $100 \mu \mathrm{L}$ to $2 \mathrm{~mL}$. Animals were observed up to 30 days after the injection. No death or other adverse manifestations were observed in this period. Thus, based on the in vitro findings and the ease of handling, the concentration of $5 \mathrm{mg} / \mathrm{kg}(156 \mathrm{mM})$ in a volume of $100 \mu \mathrm{L}$ was used in the experiments.

Once tumors became palpable, animals were given daily intraperitoneal injections of 7KCLDE (156 mM, $100 \mu \mathrm{L}$ volume) for 10 days $(n=8)$. Controls received injections of the same volume of either LDE alone $(n=7)$ or saline $(n=5)$.

Plasma $\gamma$-globulin, transaminases, alkaline protease, total bilirubin, urea, and creatinine were determined at baseline and after ten days of treatment. Blood was collected from the axillary plexus. At the end of the experimental period, bone marrow was collected from a femur of each animal. Spleen cellularity was also analyzed.

Tumor size was measured with a caliper, and the volume was estimated with the formula $\mathrm{V}=\pi / 6 \times$ $(\text { perpendicular diameter) })^{2} \times$ largest diameter [63]. Microscopical images were obtained after staining with H\&E (necrotic areas) and Verhoeff (vascularization). Survival time was also recorded for each animal.

\section{Statistical analysis}

All data are expressed as the mean \pm SD for at least three independent experiments. Non-parametrics statistical tests (Kruskal-Wallis and Mann-Whitney $U$ tests) were used to analyze the significance of the differences of blood biochemical parameters. Other data were analyzed by the two-tailed Student's $t$ test for paired samples. One way ANOVA on Graph Pad Prism with the log-rank test was used for the survival data analysis. The level of statistical significance was set at $p<0.05$.

\section{Author contributions}

GMF, AHO, DAM, EGC, RSSM, and DFD performed the experiments. GMF, RC, RCM, and SPB analyzed the data. GMF, RC, RCM, and SPB designed the experiments. GMF, RCM and SPB wrote the manuscript. All authors corrected the manuscript. SPB conceived the study.

\section{CONFLICTS OF INTEREST}

The authors declare no competing financial interest or other conflicts of interest.

\section{FUNDING AND GRANT SUPPORT}

This study was supported by grants from the Conselho Nacional de Pesquisa e Desenvolvimento (CNPq), Brazil; Fundação de Amparo à Pesquisa do Estado de São Paulo (FAPESP, Proc.00/09011-5), São Paulo, Brazil; Financiadora de Estudos e Projetos (FINEP,01.10.0779.00); Instituto Nacional de Ciência e Tecnologia em Fluidos Complexos (INCT-Fx), Brazil; and Instituto Nacional de Ciência e Tecnologia em Medicina Regenerativa (INCT-Regenera), Brazil.

\section{REFERENCES}

1. Kulig W, Cwiklik L, Jurkiewicz P, Rog T, Vattulainen I. Cholesterol oxidation products and their biological importance. Chem Phys Lipids. 2016; 199:144-160. 
2. Zerbinati C, Iuliano L. Cholesterol and related sterols autoxidation. Free Radic Biol Med. 2017; 111:151-155.

3. Jusakul A, Yongvanit P, Loilome W, Namwat N, Kuver R. Mechanisms of oxysterol-induced carcinogenesis. Lipids Health Dis. 2011; 10:44.

4. Ruiz JL, Fernandes LR, Levy D, Bydlowski SP. Interrelationship between ATP-binding cassette transporters and oxysterols. Biochem Pharmacol. 2013; 86:80-88.

5. Levy D, Ruiz JL, Celestino AT, Silva SF, Ferreira AK, Isaac C, Bydlowski SP. Short-term effects of 7-ketocholesterol on human adipose tissue mesenchymal stem cells in vitro. Biochem Biophys Res Commun. 2014; 446:720-725.

6. Mutemberezi V, Guillemot-Legris O, Muccioli GG. Oxysterols: from cholesterol metabolites to key mediators. Prog Lipid Res. 2016; 64:152-169.

7. O'Callaghan YC, Woods JA, O'Brien NM. Comparative study of the cytotoxicity and apoptosis-inducing potential of commonly occurring oxysterols. Cell Biol Toxicol. 2001; 17:127-137.

8. Nury T, Zarrouk A, Mackrill JJ, Samadi M, Durand P, Riedinger JM, Doria M, Vejux A, Limagne E, Delmas D, Prost M, Moreau T, Hammami M, et al. Induction of oxiapoptophagy on $158 \mathrm{~N}$ murine oligodendrocytes treated by 7-ketocholesterol-, 7 $\beta$-hydroxycholesterol-, or 24(S)-hydroxycholesterol: protective effects of $\alpha$-tocopherol and docosahexaenoic acid (DHA; C22:6n-3). Steroids. 2015; 99:194-203.

9. Berthier A, Lemaire-Ewing S, Prunet C, Montange T, Vejux A, Pais de Barros JP, Monier S, Gambert P, Lizard G, Néel D. 7-Ketocholesterol-induced apoptosis. Involvement of several pro-apoptotic but also anti-apoptotic calcium-dependent transduction pathways. FEBS J. 2005; 272:3093-104.

10. Prunet C, Lemaire-Ewing S, Ménétrier F, Néel D, Lizard G, Lizard G. Activation of caspase-3-dependent andindependent pathways during 7-ketocholesterol- and 7betahydroxycholesterol-induced cell death: a morphological and biochemical study. J Biochem Mol Toxicol. 2005; 19:311-326.

11. Silva SF, Levy D, Ruiz JL, de Melo TC, Isaac C, Fidelis ML, Rodrigues A, Bydlowski SP. Oxysterols in adipose tissue-derived mesenchymal stem cell proliferation and death. J Steroid Biochem Mol Biol. 2017; 169:164-75.

12. Rosa Fernandes L, Stern AC, Cavaglieri RC, Nogueira FC, Domont G, Palmisano G, Bydlowski SP. 7-Ketocholesterol overcomes drug resistance in chronic myeloid leukemia cell lines beyond MDR 1 mechanism. J Proteomics. 2017; 151:12-23.

13. Silvente-Poirot S, Poirot M. Cholesterol epoxide hydrolase and cancer. Curr Opin Pharmacol. 2012; 12:696-703.

14. Poirot M, Silvente-Poirot S. Cholesterol-5,6-epoxides: Chemistry, biochemistry, metabolic fate and cancer. Biochimie. 2013; 95:622-631.
15. Kloudova A, Guengerich FP, Soucek P. The role of oxysterols in human cancer. Trends Endocrinol Metab. 2017; 28:485-496.

16. Pfisterer SG, Peränen J, Ikonen E. LDL-cholesterol transport to the endoplasmic reticulum: current concepts. Curr Opin Lipidol. 2016; 27:282-287.

17. Ho YK, Smith RG, Brown MS, Goldstein JL. Lowdensity lipoprotein (LDL) receptor activity in human acute myelogenous leukemia cells. Blood. 1978; 52:1099-1114.

18. Kuzu OF, Noory MA, Robertson GP. The role of cholesterol in cancer. Cancer Res. 2016; 76:2063-2070.

19. Vitols S, Angelin B, Ericsson S, Gahrton G, Juliusson G, Masquelier M, Paul C, Peterson C, Rudling M, SöderbergReid K. Uptake of low density lipoproteins by human leukemic cells in vivo: relation to plasma lipoprotein levels and possible relevance for selective chemotherapy. Proc Natl Acad Sci USA. 1990; 87:2598-2602.

20. Dubowchik GM, Firestone RA. Improved cytotoxicity of antitumor compounds deliverable by the LDL pathway. Bioconjug Chem. 1995; 6:427-439.

21. Ye J, Xia X, Dong W, Hao H, Meng L, Yang Y, Wang R, Lyu Y, Liu Y. Cellular uptake mechanism and comparative evaluation of antineoplastic effects of paclitaxel-cholesterol lipid emulsion on triple-negative and non-triple-negative breast cancer cell lines. Int J Nanomedicine. 2016; 11:4125-4140.

22. Maranhão RC, Cesar TB, Pedroso-Mariani SR, Hirata MH, Mesquita $\mathrm{CH}$. Metabolic behavior in rats of a nonprotein microemulsion resembling low- density lipoprotein. Lipids. 1993; 28:691-696.

23. Maranhão RC, Garicochea B, Silva EL, Dorlhiac-Llacer P, Cadena SM, Coelho IJ, Meneghetti JC, Pileggi FJ, Chamone DA. Plasma kinetics and biodistribution of a lipid emulsion resembling low-density lipoprotein in patients with acute leukemia. Cancer Res. 1994; 54:4660-4666.

24. Hungria VT, Latrilha MC, Rodrigues DG, Bydlowski SP, Chiattone CS, Maranhão RC. Metabolism of a cholesterolrich microemulsion (LDE) in patients with multiple myeloma and a preliminary clinical study of LDE as a drug vehicle for the treatment of the disease. Cancer Chemother Pharmacol. 2004; 53:51-60.

25. Rodrigues DG, Maria DA, Fernandes DC, Valduga CJ, Couto RD, Ibañez OC, Maranhão RC. Improvement of paclitaxel therapeutic index by derivatization and association to a cholesterol-rich microemulsion: in vitro and in vivo studies. Cancer Chemother Pharmacol. 2005; 55:565-576.

26. Mendes S, Graziani SR, Vitório TS, Padoveze AF, Hegg R, Bydlowski SP, Maranhão RC. Uptake by breast carcinoma of a lipidic nanoemulsion after intralesional injection into the patients: a new strategy for neoadjuvant chemotherapy. Gynecol Oncol. 2009; 112:400-404.

27. Favero GM, Maranhão RC, Maria DA, Levy D, Bydlowski SP. Synthetic nanoemulsion resembling a protein-free model 
of 7-ketocholesterol containing low density lipoprotein: In vitro and in vivo studies. Biol Res. 2010; 43:439-444.

28. Giovannini C, Matarrese P, Scazzocchio B, Sanchez M, Masella R, Malorni W. Mitochondria hyperpolarization is an early event in oxidized low-density lipoprotein-induced apoptosis in Caco-2 intestinal cells. FEBS Lett. 2002; 523:200-206.

29. Sola B, Poirot M, de Medina P, Bustany S, Marsaud V, Silvente-Poirot S, Renoir JM. Antiestrogen-binding site ligands induce autophagy in myeloma cells that proceeds through alteration of cholesterol metabolism. Oncotarget. 2013; 4:911-22. https://doi.org/10.18632/oncotarget.1066.

30. Bydlowski SP, Yunker RL, Subbiah MT. Ontogeny of 6-keto-PGF1 alpha synthesis in rabbit aorta and the effect of premature weaning. Am J Physiol. 1987; 252:H14-21.

31. Bydlowski SP, Yunker RL, Rymaszewski Z, Subbiah MT. Coffee extracts inhibit platelet aggregation in vivo and in vitro. Int J Vitam Nutr Res. 1987; 57:217-223.

32. Ferreira AK, Freitas VM, Levy D, Ruiz JL, Bydlowski SP, Rici RE, Filho OM, Chierice GO, Maria DA. Antiangiogenic and anti-metastatic activity of synthetic phosphoethanolamine. PLoS One. 2013; 8:e57937.

33. Huang C, Freter C. Lipid metabolism, apoptosis and cancer therapy. Int J Mol Sci. 2015; 16:924-949.

34. de Weille J, Fabre C, Bakalara N. Oxysterols in cancer cell proliferation and death. Biochem Pharmacol. 2013; $86: 154-160$.

35. Luu W, Sharpe LJ, Capell-Hattam I, Gelissen IC, Brown AJ. Oxysterols: old tale, new twists. Annu Rev Pharmacol Toxicol. 2016; 56:447-467.

36. Nury T, Zarrouk A, Vejux A, Doria M, Riedinger JM, Delage-Mourroux R, Lizard G. Induction of oxiapoptophagy, a mixed mode of cell death associated with oxidative stress, apoptosis and autophagy, on 7-ketocholesterol-treated 158N murine oligodendrocytes: Impairment by $\alpha$-tocopherol. Biochem Biophys Res Commun. 2014; 446: 714-719.

37. Pedruzzi E, Guichard C, Ollivier V, Driss F, Fay M, Prunet C, Marie JC, Pouzet C, Samadi M, Elbim C, O'dowd Y, Bens M, Vandewalle A, et al. NAD(P)H oxidase Nox-4 mediates 7-ketocholesterol-induced endoplasmic reticulum stress and apoptosis in human aortic smooth muscle cells. Mol Cell Biol. 2004; 24:10703-10717.

38. Poirot M, Silvente-Poirot S. Oxysterols and related sterols: Implications in pharmacology and pathophysiology. Biochem Pharmacol. 2013; 86:1-2.

39. Chang MC, Chen YJ, Liou EJ, Tseng WY, Chan CP, Lin HJ, Liao WC, Chang YC, Jeng PY, Jeng JH. 7-Ketocholesterol induces ATM/ATR, Chk1/Chk2, PI3K/Akt signalings, cytotoxicity and IL-8 production in endothelial cells. Oncotarget. 2016; 7:74473-83. https://doi.org/10.18632/ oncotarget. 12578 .

40. Levy D, de Melo TC, Ruiz JL, Bydlowski SP. Oxysterols and mesenchymal stem cell biology. Chem Phys Lipids. 2017; 207:223-230.
41. Rosa-Fernandes L, Maselli LM, Maeda NY, Palmisano G, Bydlowski SP. Outside-in, inside-out. Proteomic analysis of endothelial stress mediated by 7-ketocholesterol. Chem Phys Lipids. 2017; 207:231-238.

42. Mo ZC, Ren K, Liu X, Tang ZL, Yi GH. A high-density lipoprotein-mediated drug delivery system. Adv Drug Deliv Rev. 2016; 106:132-147.

43. Su HT, Li X, Liang DS, Qi XR. Synthetic low-density lipoprotein (sLDL) selectively delivers paclitaxel to tumor with low systemic toxicity. Oncotarget. 2016; 7:51535-52. https://doi.org/10.18632/oncotarget.10493.

44. McMahon KM, Scielzo C, Angeloni NL, Deiss-Yehiely E, Scarfo L, Ranghetti P, Ma S, Kaplan J, Barbaglio F, Gordon LI, Giles FJ, Thaxton CS, Ghia P. Synthetic highdensity lipoproteins as targeted monotherapy for chronic lymphocytic leukemia. Oncotarget. 2017; 8:11219-27. https://doi.org/10.18632/oncotarget.14494.

45. Wilhelm S, Tavares AJ, Dai Q, Ohta S, Audet J, Dvorak HF, Chan WC. Analysis of nanoparticle delivery to tumours. Nature Rev Mater. 2016; 1:1-12.

46. Pinheiro KV, Hungria VT, Ficker ES, Valduga CJ, Mesquita $\mathrm{CH}$, Maranhão RC. Plasma kinetics of a cholesterol-rich microemulsion (LDE) in patients with Hodgkin's and non-Hodgkin's lymphoma and a preliminary study on the toxicity of etoposide associated with LDE. Cancer Chemother Pharmacol. 2006; 57:624-630.

47. Pires LA, Hegg R, Valduga CJ, Graziani SR, Rodrigues DG, Maranhão RC. Use of cholesterol-rich nanoparticles that bind to lipoprotein receptors as a vehicle to paclitaxel in the treatment of breast cancer: pharmacokinetics, tumor uptake and a pilot clinical study. Cancer Chemother Pharmacol. 2009; 63:281-287.

48. Biasi F, Leonarduzzi G, Vizio B, Zanetti D, Sevanian A, Sottero B, Verde V, Zingaro B, Chiarpotto E, Poli G. Oxysterol mixtures prevent proapoptotic effects of 7-ketocholesterol in macrophages: implications for proatherogenic gene modulation. FASEB J. 2004; 18:693-695.

49. Leonarduzzi G, Biasi F, Chiarpotto E, Poli G. Trojan horselike behavior of a biologically representative mixture of oxysterols. Mol Aspects Med. 2004; 25:155-167.

50. Miguet-Alfonsi C, Prunet C, Monier S, Bessède G, LemaireEwing S, Berthier A, Ménétrier F, Néel D, Gambert P, Lizard G. Analysis of oxidative processes and of myelin figures formation before and after the loss of mitochondrial transmembrane potential during $7 \beta$-hydroxycholesterol and 7-ketocholesterol-induced apoptosis: comparison with various pro-apoptotic chemicals. Biochem Pharmacol. 2002; 64:527-541.

51. Takano K, Sato K, Negishi Y, Aramaki Y. Involvement of actin cytoskeleton in macrophage apoptosis induced by cationic liposomes. Arch Biochem Biophys. 2012; 518:89-94.

52. Jeyaraju DV, Hurren R, Wang X, MacLean N, Gronda M, Shamas-Din A, Minden MD, Giaever G, Schimmer AD. A 
novel isoflavone, ME-344, targets the cytoskeleton in acute myeloid leukemia. Oncotarget. 2016; 7:49777-85. https:// doi.org/10.18632/oncotarget.10446.

53. Joo EE, Yamada KM. Post-polymerization crosstalk between the actin cytoskeleton and microtubule network. Bioarchitecture. 2016; 6:53-59.

54. Lizard G, Moisant M, Cordelet C, Monier S, Gambert P, Lagrost L. Induction of similar features of apoptosis in human and bovine vascular endothelial cells treated by 7-ketocholesterol. J Pathol. 1997; 183:330-338.

55. Huot J, Houle F, Marceau F, Landry J. Oxidative stressinduced actin reorganization mediated by the p38 mitogenactivated protein kinase/heat shock protein 27 pathway in vascular endothelial cells. Circ Res. 1997; 80:383-392.

56. Zahm JM, Baconnais S, Monier S, Bonnet N, Bessède G, Gambert P, Puchelle E, Lizard G. Chronology of cellular alterations during 7-ketocholesterol-induced cell death on A7R5 rat smooth muscle cells: Analysis by time lapse-video microscopy and conventional fluorescence microscopy. Cytometry A. 2003; 52:57-69.

57. Lopes AA, Peranovich TM, Maeda NY, Bydlowski SP. Differential effects of enzymatic treatments on the storage and secretion of von Willebrand factor by human endothelial cells. Thromb Res. 2001; 101:291-297.
58. Janz FL, Debes AA, Cavaglieri RC, Duarte SA, Romão CM, Morón AF, Zugaib M, Bydlowski SP. Evaluation of distinct freezing methods and cryoprotectants for human amniotic fluid stem cells cryopreservation. J Biomed Biotechnol. 2012; 2012:649353.

59. Goldstein JL, Basu SK, Brown MS. Receptor-mediated endocytosis of low-density lipoprotein in cultured cells. Methods Enzymol. 1983; 98:241-60.

60. Vindelov LL, Christensen IJ, Nissen NI. A detergent-trypsin method for the preparation of nuclei for flow cytometric DNA analysis. Cytometry. 1983; 3:323-327.

61. Cossarizza A, Baccarani-Contri M, Kalashnikova G, Franceschi C. A new method for the cytofluorimetric analysis of mitochondrial membrane potential using the J-aggregate forming lipophilic cation 5,5',6,6'-tetrachloro1,1',3,3'-tetraethylbenzimidazolcarbocyanine iodide (JC-1). Biochem Biophys Res Commun. 1993; 197:40-45.

62. Biederbick A, Kern HF, Elsasser HP. Monodansylcadaverine (MDC) is a specific in vivo marker for autophagic vacuoles. Eur J Cell Biol. 1995; 66:3-14.

63. Luo H, Lu L, Yang F, Wang L, Yang X, Luo Q, Zhang Z. Nasopharyngeal cancer-specific therapy based on fusion peptide-functionalized lipid nanoparticles. ACS Nano. $2014 ; 8: 4334-4347$. 